\title{
Akseptabilitas Alumni Jurusan Al- Ahwal Al-Syakhsiyah Fakultas Syari'ah Dan Hukum UIN Sumatera Utara Pada Ujian Calon Hakim Peradilan Agama Di Mahkamah Agung Ri Tahun 2017
}

\author{
Ibnu Radwan Siddik Turnip* \& Amal Hayati** \\ Universitas Islam Negeri Sumatera Utara, Medan \\ Email: ibnuradwan@uinsu.ac.id
}

\begin{abstract}
This study will try to describe how the acceptability of Al-Ahwal AlSyakhsiyah (AS) alumni of the Faculty of Shari'ah and Law UIN Sumatera Utara in the selection of Judicial Candidates for Religious Courts in 2017. What factors are the causes of alumni failure and what solutions can be done so that more alumni pass the selection of Religious Judges. This research uses mixed methods research, which is a research step by combining two forms of approach in research, namely qualitative and quantitative. The results showed that at the Faculty level, the acceptability of AS alumni was quite high, but nationally it was still relatively low. Among the alumni failure factors is because the alumni are more focused in preparing Field Competency Selection (SKB) which is considered more difficult than Basic Competency Selection (SKD), the exam time given to SKD exam participants is relatively short to answer, the SKD questions given are quite difficult to answer, especially the questions related to TIU and

* Dosen Prodi Ahwal Syakhshiyah, Fakultas Syariah dan Hukum UIN Sumatera Utara.

** Dosen Prodi Ahwal Syakhshiyah, Fakultas Syariah dan Hukum UIN Sumatera Utara.
\end{abstract}


Akseptabilitas Alumni Jurusan Al-Ahwal Al-Syakhsiyah .... 2

TKP, the SKD passing grade is quite high and the computer system usage (CAT) factors in the SKD exam are not familiar.

Keywords: Alumni, Al-Ahwal Al-Syakhsiyah, Religious Court, Judge's profession

\section{Abstrak}

Penelitian ini akan mencoba menguraikan bagaimana sebenarnya akseptabilitas alumni Al-Ahwal Syakhsiyah (AS) Fakultas Syari'ah dan Hukum UIN Sumatera Utara pada seleksi Calon Hakim Peradilan Agama tahun 2017. Faktor-faktor apa saja yang menjadi penyebab ketidaklulusan alumni dan solusi apa yang bisa dilakukan agar para alumni lebih banyak lagi lulus dalam seleksi Calon Hakim Peradilan Agama. Penelitian ini menggunakan jenis penelitian mixed methods, yaitu suatu langkah penelitian dengan menggabungkan dua bentuk pendekatan dalam penelitian, yakni kualitatif dan kuantitaitf. Hasil penelitian menunjukkan bahwa pada tingkat Fakultas, akseptabilitas alumni AS cukup tinggi, namun secara nasional masih relatif rendah. Di antara faktor ketidaklulusan alumni adalah karena para alumni lebih fokus dalam mempersiapkan Seleksi Kompetensi Bidang (SKB) yang dianggap lebih sulit daripada Seleksi Kompetensi Dasar (SKD), waktu ujian yang diberikan kepada peserta ujian SKD relatif singkat untuk menjawab soal-soal yang berhubungan dengan kompetensi dasar seperti TWK, TIU dan TKP, soal-soal SKD yang diberikan cukup sulit untuk dijawab terlebih soal-soal yang berhubungan dengan TIU dan TKP , passing grade SKD cukup tinggi dan faktor penggunaan sistem computer (CAT) dalam ujian SKD yang belum terbiasa.

Kata Kunci: Alumni, Al-Ahwal Al-Syakhsiyah, Peradilan Agama, Profesi Hakim.

\section{Pendahuluan}

enjadi hakim merupakan cita- cita sebagian besar mahasiswa Jurusan Al-Ahwal Al-Syakhsiyah (AS) yang juga merupakan profil utama dari Jurusan ini yang sebelumnya Jurusan ini bernama Jurusan Peradilan 
Agama. Profil utama lulusan adalah praktisi hukum Islam atau Calon Hakim Peradilan Agama yang berkepribadian baik, berpengetahuan luas dan mutakhir, serta mampu melaksanakan tugas umum sebagai praktisi hukum Islam atau calon Hakim Peradilan Agama dan tugas khusus sebagai praktisi hukum keluarga Islam sesuai dengan kode etik keilmuan dan keahlian. 1 Profesi hakim menjadi nilai jual dan bagian dari promosi, sehingga dari lima jurusan yang ada di Fakultas Syari'ah dan Hukum UIN SU saat ini, jurusan AS memiliki mahasiswa dengan jumlah terbanyak ${ }^{2}$ Untuk menyahuti keinginan besar peminat jurusan AS ini, pengelola Jurusan mendesain kurikulum Jurusan sedemikian rupa, menyesuaikannya dengan kebutuhan stoke holder agar mahasiswa dapat berkompetisi dan memenangkan persaingan menjadi hakim. Mata kuliah yang diajarkan pun disusun agar mendukung misi tersebut

Dalam kenyataannya, pada tes penerimaan calon Hakim Peradilan Agama Mahkamah Agung RI tahun 2017, kontestan dari alumni Jurusan AS Fakultas Syari'ah dan Hukum UIN SU Medan relatif sedikit yang lulus. Berdasarkan hasil integrasi nilai Seleksi Kompetensi Dasar (SKD) dan Seleksi Kompetensi Bidang SKB), Panitia Seleksi Nasional CPNS mengumumkan ada 454 peserta yang lulus dari Formasi Umum, 9 peserta jalur Formasi Putra Putri Papua, 62 peserta Formasi Lulusan Terbaik (Cumlaude). ${ }^{3}$ Dari 454 peserta ujian yang lulus seluruh

${ }^{1}$ Lihat: Tim Penyusun Buku Panduan Akademik UIN SU, Buku Panduan Akademik UIN Sumatera Utara TA. 2015/2016, 147.

2 Berdasarkan data pengumuman hasil ujian masuk dan mahasiswa pendaftar ulang terlihat dari tahun ke tahun Jurusan AS memiliki mahasiswa terbanyak. Tahun Akademik 2017-2018 jumlah mahasiswa baru untuk Jurusan AS sebanyak 193 mahasiswa, sementara jurusan lain masing-masing; Jurusan Muamalah 166 mahasiswa, Jurusan Siyasah 166 mahasiswa, Jurusan Jinayat 126 mahasiswa dan Jurusan Perbandingan Mazhab 102 mahasiswa.

${ }^{3}$ Lihat Lampiran Surat Menteri Pendayagunaan Aparatur Negara dan Reformasi Birokrasi selaku Ketua Tim Pengarah Panselnas Nomor B/554/S.SM.01.00/2017 tanggal 3 November 2017 tentang Hasil Nilai Integrasi

Ulul Albab: Jurnal Studi dan Penelitian Hukum Islam 
Akseptabilitas Alumni Jurusan Al-Ahwal Al-Syakhsiyah .... 4

Indonesia dari Formasi Umum, 7 orang saja yang tercatat merupakan alumni Jurusan Al-Ahwal Al-Syakhsiyah FASIH UIN SU.4

Bagaimana sebenarnya akseptabilitas alumni Al-Ahwal Al-Syakhsiyah Fakultas Syari'ah dan Hukum (FASIH) UIN Sumatera Utara pada penerimaan calon Hakim peradilan Agama di Mahkamah Agung Tahun 2017? Apa sebenarnya yang menjadi kendala bagi alumni AS FASIH UINSU sehingga banyak yang gugur pada tes calon Hakim Peradilan Agama? Bagaimana sebenarnya format tes SKD dan SKBtersebut? Materi-materi apa saja yang dipertanyakan pada soal-soal tes SKD dan SKB itu? Apakah ada kebijakan dari Fakultas atau Jurusan untuk membekali alumninya dalam menghadapi tes Hakim Peradilan Agama tersebut? Apa solusi yang bisa dilakukan Jurusan dalam menyongsong tes Hakim Peradilan Agama di masa akan datang yang mungkin akan dilakukan lagi? Kiranya pertanyaan-pertanyaan ini membutuhkan satu penelitian yang serius sehingga dapat memberikan masukan bagi Jurusan Al-Ahwal Al-Syaksiyah Khususnya, dan bagi FASIH dan UIN Sumatera Utara pada umumnya.

\section{Landasan Teoritis Dan Kajian Terdahulu}

\section{Peradilan Agama}

Peradilan Agama adalah salah satu peradilan yang berada dibawah naungan Mahkamah Agung. Berdasarkan pasal 11 ayat 1 Undang-undang No. 35 Tahun 1999 tentang Perubahan Atas Undang-undang No. 14 tahun 1970 tentang Ketentuan-ketentuan Pokok Kekuasaan Kehakiman ditegaskan

SKD dan SKB Seleksi CPNS Tahun 2017 Instansi Mahkamah Agung Unit Peradilan Agama Formasi Jabatan Calon Hakim

${ }^{4}$ Hasil wawancara dengan Fachruddin Zakarya, alumni Tahun 2017 Jurusan Al-Ahwal Al-Syaksiyyah yang lulus dalam Ujian CPNS Hakim Agama 2017.. Fachruddin Zakarya, Alumni Jurusan AS, Wawancara Pribadi, Medan, 3 Nopember 2017. 
5 Ibnu Radwan Siddik Turnip \& Amal Hayati

bahwa semua badan peradilan meliputi Peradilan Umum, Peradilan Agama, Peradilan Militer dan Peradilan Tata Usaha Negara secara organisatoris, administrasi dan finansial berada di bawah Mahkamah Agung. Peradilan Agama, Peradilan Militer dan Peradilan Tata Usaha Negara merupakan Peradilan khusus karena hanya mengadili perkara tertentu dan untuk golongan rakyat tertentu. ${ }^{5}$

Peradilan Agama hanya berwenang untuk mengadili perkara perdata Islam bagi mereka yang beragama Islam. Peradilan Militer hanya berwenang untuk mengadili perkara pidana yang dilakukan oleh oknum militer. Sedangkan Peradilan Tata Usah Negara hanya mengadili sengketa tata usaha negara antara rakyat dengan pejabat. Peradilan Umum adalah peradilan bagi rakyat pada umumnya baik mengenai perkara perdata maupun perkara pidana. ${ }^{6}$

Peradilan Agama merupakan salah satu pelaksana kekuasaan kehakiman bagi rakyat pencari keadilan bagi yang beragama Islam, mengenai perkara perdata tertentu yang diatur dalam Undang-undang.

Peradilan Agama terdiri dari:

a. Peradilan Agama sebagai pengadilan tingkat pertama yang berkedudukan di kotamadya atau ibu kota kabupaten dengan wilayah hukum meliputi wilayah kotamadya dan kabupaten.

b. Pengadilan Tinggi Agama sebagai pengadilan tingkat banding yang berkedudukan di ibu kota provinsi dan daerah hukumnya meliputi wilayah provinsi.

${ }^{5}$ Kekuasaan Kehakiman tersebut dilakukan oleh Pengadilan dalam lingkungan Kekuasaan Kehakiman tersebut dilakukan oleh Pengadilan dalam lingkungan Peradilan Umum, Peradilan Agama, Peradilan Tata Usaha Negara dan Peradilan Militer. Lihat M. Yahya Harahap, Hukum Acara Perdata (Jakarta: Sinar Grafika, 2013), h.180.

6 Mukti Arto, Praktek Perkara Perdata Pada Pengadilan Agama. (Yokyakarta: Pustaka Pelajar, 2008),.15.

Ulul Albab: Jurnal Studi dan Penelitian Hukum Islam 
Akseptabilitas Alumni Jurusan Al-Ahwal Al-Syakhsiyah .... 6

Peradilan Agama berpuncak pada Mahkamah Agung yang berkedudukan di ibukota Negara R.I. yaitu di Jakarta. Peradilan Agama dibentuk dengan keputusan Presiden. Pengadila Tinggi Agama dibentuk dengan Undang-undang. Mahkamah Agung dibentuk berdasarkan Undang-undang Dasar 45 pasal 24.

\section{Profesi Hakim}

Salah satu elemen yang sangat penting dalam sistem peradilan adanya ketersediaan seorang hakim dalam memutuskan setiap perkara. Profesi hakim memiliki kedudukan dan peranan yang penting demi tegaknya negara hukum. Oleh karena itu, terdapat beberapa nilai yang dianut dan wajib dihormati oleh penyandang profesi hakim dalam menjalankan tugasnya. Nilai di sini diartikan sebagai sifat atau kualitas dari sesuatu yang bermanfaat bagi kehidupan manusia, baik lahir maupun batin. Profesi hakim sebagai salah satu bentuk profesi hukum sering digambarkan sebagai pemberi keadilan. Oleh karena itu, hakim juga digolongkan sebagai profesi luhur (officium nobile), yaitu profesi yang pada hakikatnya merupakan pelayanan pada manusia dan masyarakat. Setiap profesi memiliki etika yang pada prinsipnya terdiri dari kaidah-kaidah pokok sebagai berikut:

1. Profesi harus dipandang sebagai pelayanan, oleh karenanya, sifat "tanpa pamrih" menjadi ciri khas dalam mengembangkan profesi.

2. Pelayanan profesional dalam mendahulukan kepentingan pencari keadilan mengacu pada nilai-nilai luhur.

3. Pengembanan profesi harus selalu berorientasi pada masyarakat sebagai keseluruhan. 
7 Ibnu Radwan Siddik Turnip \& Amal Hayati

4. Persaingan dalam pelayanan berlangsung secara sehat sehingga dapat menjamin mutu dan peningkatan mutu pengemban profesi. ${ }^{7}$

Berdasarkan Keputusan Bersama Ketua Mahkamah Agung RI dan Ketua Komisi Yudisial RO Nomor 047/KMA/SKB/2009 dan Peraturan Bersama Ketua Mahkamah Agung RI dan Ketua Komisi Yudisial RI Nomor 02/SKB/P.KY/IV/2009 terdapat 10 Kode Etik dan Pedoman Perilaku Hakim meliputi berprilaku adil, berprilaku jujur, berprilaku arif dan bijaksana, bersikap mandiri, berintegrasi tinggi, bertanggung jawab, menjunjung tinggi harga diri, berdisiplin tinggi, berprilaku rendah hati dan bersikap profesional. Bersikap profesional pada hakekatnya bermakna suatu sikap moral yang dilandasi oleh tekad untuk melaksanakan pekerjaan yang dipilihnya dengan kesungguhan, yang didukung oleh keahlian atas dasar pengetahuan, keterampilan dan wawasan luas. ${ }^{8}$

Hakim pada Pengadilan Agama adalah pejabat yang melaksanakan tugas kekuasaan kehakiman. Hakim Pengadilan Agama diangkat dan diberhentikan oleh Presiden atas usul Ketua Mahkamah Agung. Dalam hal rekrutmen hakim Pengadilan Agama, peraturan perundang-undangan menetapkan beberapa syarat. Pada pasal 13 dan 13 A UU No.50 Tahun 2009 tentang Perubahan Kedua UU No.7 Tahun 1989 dinyatakan.

(1) Untuk dapat diangkat sebagai hakim pengadilan agama, seseorang harus memenuhi syarat sebagai berikut:

a. Warganegara Indonesia;

${ }^{7}$ Handar Subhandi, “Karakteristik Profesi Hakim dan Tanggung Jawab Profesi Hakim," dalam http://handarsubhandi.blogspot.co.id/2014/06/katakteristi-profesi-hakim-dan.htnl, diakses tanggal 7 Nopember 2017.

8 Lihat PA Purworejo, "Kode Etik dan Pedoman Prilaku hakim” http://pa-purworejo.go.id/web/pedoman-perilaku-hakim, diakses tanggal 7 Nopember 2017.

Ulul Albab: Jurnal Studi dan Penelitian Hukum Islam 
\begin{tabular}{l|l} 
Akseptabilitas Alumni Jurusan Al-Ahwal Al-Syakhsiyah .... & 8
\end{tabular}

b. Beragama Islam;

c. Bertakwa kepada Tuhan Yang Maha Esa;

d. Setia kepada Pancasila dan Undang-Undang Dasar Negara Republik Indonesia Tahun 1945;

e. Sarjana syari'ah, sarjana hukum Islam atau sarjana hukum yang menguasai hukum Islam;

f. Lulus pendidikan hakim;

g. Mampu secara rohani dan jasmani untuk menjalankan tugas dan kewajiban;

h. Berwibawa, jujur, adil dan berkelakuan tidak tercela;

i. Berusia paling rendah 25 (dua puluh lima) tahun dan paling tinggi 40 (empat puluh) tahun; dan

j. Tidak pernah dijatuhi pidana penjara karena melakukan kejahatan berdasarkan putusan pengadilan yang telah berkekuatan hukum tetap.

(2) Untuk dapat diangkat menjadi ketua atau wakil ketua pengadilan agama, hakim harus berpengalaman paling singkat 7 (tujuh) tahun sebagai hakim pengadilan agama. "Pasal 13A:

(1) Pengangkatan hakim pengadilan agama dilakukan melalui proses seleksi yang transparan, akuntabel, dan partisipatif.

(2) Proses seleksi pengangkatan hakim pengadilan agama dilakukan bersama oleh Mahkamah Agung dan Komisi Yudisial.

(3) Ketentuan lebih lanjut mengenai proses seleksi diatur oleh Mahkamah Agung dan Komisi Yudisial.

\section{Kajian Terdahulu}

Sepanjang penelusuran peneliti, terdapat beberapa penelitian tentang alumni syariah dan kaitannya dunia Hakim Peradilan Agama. Ahmad Fauzi meneliti tentang Tanggung Jawab Akademis Fakultas Syariah dalam Perspektif UU No. 3 Tahun 2006. Penelitian ini menjelaskan dengan lahirnya UU No 
9 Ibnu Radwan Siddik Turnip \& Amal Hayati

3 tahun 2006, maka yuridiksi Peradilan Agama semakin bertambah. Salah satu yuridiksi baru tersebut adalah berkenaan dengan ekonomi syariah. Banyak kalangan yang memvonis bahwa Peradilan Agama sebagai lembaga yang kurang familiar dalam menangani sengketa perbankan. hal ini tentunya bagi Peradilan Agama harus mempersiapkan hakim-hakim yang tidak saja memiliki kecakapan dalam menangani kasus-kasus perkawinan, warisan dan wakaf tetapi juga berkenaan dengan sengketa perbankan (ekonomi). Dalam konteks inilah peranan akademisi Fakultas Syariah sangat dibutuhkan untuk mempersiapkan para alumninya menjadi calon hakim yang memiliki kemampuan untuk menjawab tantangan tersebut. Menurut Achmad Fauzi perlu adanya disain ulang dan linier antara kurikulum yang diajarkan di Fakultas Syariah dengan kebutuhan Peradilan Agama tersebut, bila tidak, maka akan terjadi ketimpangan antara kebutuhan sumber daya manusia Peradilan Agama dengan disiplin keilmuan yang diajarkan. ${ }^{9}$

Yusdani meneliti tentang Posisi Tawar Sarjana Syari'ah Menurut UU Advokat. Penelitian ini memaparkan bahwa dengan lahirnya UU No. 18 tahun 2003 Tentang Profesi Advokat memberikan peluang besar bagi alumni sarjana Syariah untuk menjadi seorang advokat tanpa adanya diskriminatif. Namun di sisi lain UU ini juga merupakan tantangan bagi alumni Syariah apakah mampu bersaing dengan Sarjana Hukum lain. Menurut Yusdani, di tengah kondisi bangsa Indonesia yang disorot karena praktek penegakan hukum yang lemah dan kejahatan korupsi sangat parah, maka keberadaan dan peran advokat dari sarjana Syari'ah dapat menampilkan alternatif baru. Advokat sarjana syari'ah dapat memberikan pencerahan bagi suasana penegakan hukum yang mendung dewasa ini. Pada saat yang

${ }^{9}$ Achmad Fauzi," Tanggungjawab Akademis Fakultas Syariah Dalam Perspektif UU No. 3 Tahun 2006", dalam Al-Mawarid, Vol.18, (Jurusan Syari'ah Fakultas Agama Islam UII Yogyakarta, 2008), 161-172.

Ulul Albab: Jurnal Studi dan Penelitian Hukum Islam 
Akseptabilitas Alumni Jurusan Al-Ahwal Al-Syakhsiyah .... $\mid 10$

sama hal ini menuntut adanya respon dari Fakultas Syariah untuk memenuhi tuntutan pemberian bekal bagi pelaksanaan peran optimal sarjana. ${ }^{1}$

Kemudian, Yusdani bersama Junanah dan Muhammad Husnul, juga telah membuat sebuah penelitian dengan judul Kompetensi Lulusan Hukum Islam Perguruan Tinggi Agama Islam di Yogyakarta. Berdasarkan hasil penelitian tentang kurikulum Fakultas Syari'ah di 3 PTAI Yogyakarta, terutama Fakultas Syariah dan Hukum UIN Sunan Kalijaga Yogyakarta. Sebagai IAIN tertua, perguruan tinggi ini tampaknya menjadi contoh bagi UIN, IAIN, STAIN dan PTAIS lainnya dalam bidang studi hukum Islam. Namun, dalam kenyataannya, studi hukum Islam di Fakultas Syari'ah dan Hukum UIN Sunan Kalijga juga masih belum menampakkan perkembangan yang menggembirakan. Jika dicermati lebih mendalam ternyata bahwa UIN Sunan Kalijaga sebagai perguruan Islam negeri terdepan, dalam kajian hukum Islam pun masih bernuansa klasik dan masih kuat sisi teologis-normatif-dekuktif atau dalam ungkapan lain hal ini menggambarkan pembelajaran hukum Islam yang old fashion. ${ }^{1}$

Dari ketiga penelitian di atas, peneliti tidak menemukan adanya pembahasan yang rinci tentang akseptabilitas alumni Syariah dan Hukum pada ujian calon hakim Peradilan Agama pada Mahkamah Agung. Berdasarkan ini, kiranya penelitian ini layak untuk diteliti karena belum ada penelitian yang sama yang telah dibuat oleh peneliti-peneliti sebelumnya.

\section{Metode Penelitian}

1 Yusdani," Posisi Tawar Sarjana Syari'ah Menurht UU Advokat," dalam Al-Mawarid, Vol. 12, (Jurusan Syari'ah Fakultas Agama Islam UII Yogyakarta ,2004), 79-90.

1 Yusdani, Junanah dan Muhammad Husnul, "Pudarnya Pesona Hukum Islam di PTAI", dalam Millah, Vol. 13, No. 2, (Magister Ilmu Agama Islam UII Yogyakarta, Februari 2014), 324-339. 
11 Ibnu Radwan Siddik Turnip \& Amal Hayati

Penelitian ini menggunakan mixed methods, yaitu suatu langkah penelitian dengan menggabungkan dua bentuk pendekatan dalam penelitian, yakni kualitatif dan kuantitaitf. Penelitian kualitatif adalah penelitian yang didasarkan pada data-data empiris, alamiah, peneliti sebagai instrumen kunci, pengambilan sample sumber data dengan cara purposive dan snowbaal, teknik pengumpulan data dengan cara pengamatan, wawancara, diskusi kelompok, dokumentasi dan trianggulasi, analisis data bersifat induktif dan hasil penelitian yang diperoleh lebih ditekankan pada makna dari pada generalisasi. ${ }^{1}$ Sementara penelitian kuantitatif adalah suatu proses menemukan pengetahuan yang menggunakan data berupa angka sebagai alat menganalisis keterangan mengenai apa yang ingin diketahui. ${ }^{1}$ Penggabungan dua metode penelitian dalam penelitian ini dikarenakan strategi pengumpulan datanya bersifat kualitatif dan kuantitatif.

Sumber data peneltian ini mengunakan dokumen, wawancara tidak terstruktur, pengamatan dan juga hasil questioner dari apara responden yang bersifat numeric dan dihitung secara statistik. Data primer diperoleh dari alumni Jurusan Al-Ahwal Al-Syakhsiyah yang tidak lulus dalam ujian calon Hakim Peradilan Agama di Mahkamah Agung Tahun

1 Sugiono, Metode Penelitian Pendidikan, Pendekatan Kuantitatif, Kualitatif, Penelitian dan Pengembangan (Bandung: Alpabet, 2014), 15.

1 Kasiram, Metodologi Penelitian Kualitatif dan Kuäntitatif, (Malang: UIN Malang Press, 2008), 149.

1 Menurut Lexy J Moleong perbedaan antara stratégi pengumpulan data kualitatif dengan kuantitafif adalah bahwa stategi pengumpulan kualitatif berupa pengumpulan dokumen, pengamatan berperan serta (participant observation), wawancara tidak terstruktur dan informal dan mencatat data dalam catatan lapangan secara intensif. Sementara startegi pengumpulan data kuantitatif bersifat numerik, variable dioperasionalkan, kode dikuantifikasikan, statistikal, dihitung dan diadakan pengukuran. Lihat Lexy J. Moleong, Metodologi Penelitian Kualitatif, (Bandung: PT. Remaja Rosdakarya, 1999), 35.

Ulul Albab: Jurnal Studi dan Penelitian Hukum Islam 
Akseptabilitas Alumni Jurusan Al-Ahwal Al-Syakhsiyah .... $\mid 12$

2017. Responden yang diambil berjumlah 22 alumni. Penentuan sampel didasarkan pada teknik purposive, mengingat sulitnya keterjangkauan peneliti dengan alumni yang sudah berdomisili di berbagai daerah. Data primer juga diambil dari keterangan dari alumni yang lulus, pimpinan Jurusan Al-Ahwal AlSyaksiyah dan Pimpinan Fakultas Syariah dan Hukum UIN SU. Sedangkan sumber data sekunder data pendukung; dokumendokumen, buku-buku, majalah, bulletin yang ada kaitannya dengan penelitian. Teknik analisis data yang dipergunakan dalam penelitian ini menggunakan teknik analisis kualitatif dan kuantitaif. Sebenarnya analisis data telah dilakukan sejak awal pengumpulan data. Analisis data sejak dini membantu untuk menghindari bertumpuknya data sehingga mempersulit pemahaman kembali akan maknanya bila dihubungkan dengan masalah penelitian. Kemudian untuk data dari questioner diolah dengan analisis kuantitatif dengan menggunakan analisis distribusi frekunsi. Distribusi frekuensi adalah susunan data menurut kelas-kelas tertentu. Menurut Suharyadi dan Purwanto, distribusi frekuensi adalah pengelompokan data ke dalam beberapa kategori yang menunjukkan banyaknya data dalam setiap kategori, dan setiap data tidak dapat dimasukkan kedalam dua atau lebih kategori. Pada tahap penyajian data, data yang sudah diklasifikasikan, disajikan atau ditampilkan dalam bentuk tabel atau grafik. ${ }^{1}$ Dengan langkah-langkah tersebut di atas, diharapkan akan diperoleh gambaran yang menyeluruh tentang akseptabilitas alumni Fakultas Syari'ah dan Hukum UIN SU Jurusan Ahwal al-Syakhshiyah (AS) pad ujian calon hakim agama di Mahkamah Agung RI Tahun 2017.

\section{Format Seleksi Calon Hakim Peradilan Agama}

1 Ulasan tentang distribusi frekuensi ini lebih leñgkap lagi dapat dilihat dalam buku karangan Suharyadi dan Purwanto berjudul Statiska Untuk Ekonomi dan Keuangan Modern. Lihat Suharyadi dan Purwanto berjudul, Statiska Untuk Ekonomi dan Keuangan Modern, (Jakarta: Salemba Empat, 2009). 
$13 \mid$ Ibnu Radwan Siddik Turnip \& Amal Hayati

\section{Seleksi Administrasi}

Dalam seleksi penerimaan calon Hakim Peradilan Agama terdapat ketentuan-kentuan umum dan persyaratanpersyaratan seperti yang berhubungan dengan batas usia pelamar, kualifikasi pendidikan, akreditasi program studi, keabsahan ijazah, nilai indeks prestasi kumulatif (IPK) dan lainlain. Pelamar terlebih dahulu melakukan registrasi on line melalui situs https://sscn.bkn.go.id dengan mengisi form yang telah disediakan menggunakan data kependudukan yang valid. Setelah melakukan registrasi online dan mendapat Kartu Pendaftaran Registrasi online, pelamar harus menyampaikan surat lamaran tertulis dengan melampirkan berkas-berkas administrasi yang dibutuhkan. Berkas-berkas tersebut dimasukkan ke dalam amplop warna coklat dan di sudut kanan atas ditempel potongan nomor pendaftaran registrasi online. Selanjutnya dikirimkan kepada Panitia Seleksi Penerimaan Calon Hakim Mahkamah Agung RI Tahun Anggaran 2017 melalui POS dengan PO BOX 2700 Jakarta 10027. Setelah memverifikasi kelengkapan dan kevalidan berkas sesuai dengan ketentuan, pihak Panitia mengumumkan pelamar-pelamar yang lulus seleksi administrasi dan dapat mencetak Kartu Tanda Peserta Ujian melalui situs https://sscn.bkn.go.id.

\section{Seleksi Kompetensi Dasar (SKD)}

Seleksi Kompetensi Dasar ini menggunakan Computer Assisted Test (CAT), dimana semua peserta ujian menjawab soalsoal yang diujikan melalui sistem komputer dan mereka bisa mengetahui hasilnya langsung apakah nilai yang mereka peroleh memenuhi passing grade (standar kelulusan) yang telah ditetapkan oleh Menteri Pendayagunaan Aparatur Negara dan Reformasi Birokrasi (PAN dan RB). Adapun materi seleksi Calon Pegawai Negeri Sipil (CPN) berdasarkan Peraturan Menteri PAN dan RB Nomor 20 Tahun 2017, terdiri dari tiga kelompok 
Akseptabilitas Alumni Jurusan Al-Ahwal Al-Syakhsiyah .... $\mid 14$

yakni Tes Wawasan Kebangsaan (TWK), Tes Intelegensi Umum (TIU) dan Tes Karakteristik Pribadi. ${ }^{1}$

Tes Wawasan Kebangsaan (TWK) diberikan untuk menilai penguasaan pengetahuan dan kemampuan mengimplementasikan nilai-nilai 4 (empat) pilar kebangsaan Indonesia yang meliputi; Pancasila, Undang-Undang Dasar 1945, Bhineka Tunggal Ika, dan Negara Kesatuan Republik Indonesia, meliputi sitem tata negara Indonesia, sejarah perjuangan bangsa, peranan bangsa Indonesia dalam tatanan regional maupun global dan kemampuan berbahasa Indonesia secara baik dan benar.

Tes Intelegensi Umum (TIU) dimaksudkan untuk menilai kemampuan verbal yaitu kemampuan menyampaikan informasi secara lisanmaupun tulis. kemampuan numerik yaitu kemampuan melakukan operasi perhitungan angka dan melihat hubungan diantara angka-angka. Kemampuan berpikir logis yaitu kemampuan melakukan penalaran secararuntut dan sistematis; dan kemampuan berpikir analitis yaitu kemampuan mengurai suatu permasalahan secara sistematik.

Tes Karakteristik Pribadi (TKP) dimaksudkan untuk menilai Integritas diri, semangat berprestasi, kreativitas dan inovasi, orientasi pada pelayanan, orientasi kepada orang lain, kemampuan beradaptasi, kemampuan mengendalikan diri, emampuan bekerja mandiri dan tuntas, kemauan dan kemampuan belajar berkelanjutan, kemampuan bekerja sama dalam kelompok dan kemampuan menggerakkan dan mengkoordinir orang lain.

Agar lolos ke tahapan berikutnya, peserta seleksi harus lulus atau melewati ambang batas (passing grade) yang ditetapkan dengan Peraturan Menteri PAN dan RB. Dikutip dari laman resmi Kemen PANRB, melalui Peraturan Menteri Pendayagunaan Aparatur Negara dan Reformasi Birokrasi

${ }^{1}$ Lihat Peraturan Menteri PAN dan RB Nomor 20 Tahun 2017. 
$15 \mid$ Ibnu Radwan Siddik Turnip \& Amal Hayati

(PANRB) no 22/2017, pemerintah menetapkan nilai ambang batas (passing grade) Seleksi Kompetensi Dasar (SKD) CPNS tahun 2017. Passing grade tahun ini 143 untuk Tes Karakteristik Pribadi (TKP), 80 untuk Intelegensia Umum (TIU) dan 75 untuk Tes Wawasan Kebangsaan (TWK). Adapun jumlah soal yang diberikan pada TKP sebanyak 35 soal, TIU 30 soal dan TWK 35 soal. Semua soal berjumlah 100 buah dan waktu yang diberikan untuk menyelesaikan 100 soal tersebut adalah 90 menit atau 5.400 detik. Ini artinya satu soal harus diselesaikan dalam waktu 54 detik.

\section{Seleksi Kompetensi Bidang (SKB)}

Seleksi Kompetensi Bidang (SKB) untuk calon Hakim Peradilan Agama dibagi ke dalam SKB 1, SKB 2 dan SKB 3. Masing-masing bobot nilainya adalah SKB 1 bobotnya $50 \%$, SKB 2 bobotnya $25 \%$ dan wawancara bobotnya $25 \%$. Tes SKB 1 yang menguji kemampuan materi di bidang hukum menggunakan Computer Assisted Test (CAT). Materi-materi soalnya berkisar tentang pengetahuan ilmu hukum umum, hukum perdata dan hukum acara perdata dan sebagian kecil tentang hukum Islam. ${ }^{1}$

Tes SKB 2 adalah tes psikotes dimana setiap peserta disuguhi materi-materi tes yang berhubungan dengan tes

1 Menurut Fakhrudin Zakaria, Alumni Jurusan AS yang lulus tes cakim Peradilan Agama, ketika ujian SKB 1 tentang pengetahuan di bidang hukum, ia tidak menemukan soal-soal yang berhubungan dengan fiqh Islam atau kajian hukum Islam lainnya. Wawancara Pribadi, Faacruddin Zakaria, 12 Oktoiber 2018. Tetapi menurut Muhammad Idris, Alumni AS yang lulus juga, ia menemukan beberapa soal yang berhubungan tentang hukum Islam tetapi berkenaan tentang Hukum Jinayat dan Hukum Ekonomi Syari'ah. Muhammad Idris, Alumni Jurusan AS, Wawancara Pribadi, Medan, 12 Oktober 2018. Hal ini bisa dipahami karena tiap beserta akan berbeda soa-soal yang diberikan dengan menggunakan sistim CAT. Panitia Seleksi sendiri telah menyediakan Test Materi Bidang Hukum dengan Computer Assisted Test (CAT), soal sebanyak 3000 masing-masing 1000/ lingkungan peradilan sudah diintegrasikan ke sistem CAT BKN pada Rabu 20 September 2017 di Kantor Kementerian PAN \& RB.

Ulul Albab: Jurnal Studi dan Penelitian Hukum Islam 
Akseptabilitas Alumni Jurusan Al-Ahwal Al-Syakhsiyah .... $\mid 16$

psikotes. Biasanya tes psikotes untuk cpns itu meliputi beberapa tes seperti Tes Kemampuan Numerik, Tes Kemampuan Spasial, Tes Kemampuan Reasoning dan Tes Kemampuan Mengingat (memori). Tes kemampuan numerik, yaitu tes ketelitian, ketepatan, dan kecepatan dalam berhitung. Tes antara lain tes deret angka, matematika dan tes berhitung cepat. Tes kemampuan spasial yaitu tes kemampuan menggambarkan, melukiskan, dan membayangkan sebuah gambar atau objek. Tes yang diujikan yaitu tes gambar. Tes kemampuan reasoning yaitu tes kemampuan seseorang dalam memecahkan suatu masalah. Tes mengingat yaitu kemampuan daya ingat dan kreativitas berpikir pada saat menyelesaikan ssuatu masalah.

Tes SKB 3 adalah wawancara. Untuk penguji wawancara calon Hakim Peradilan Agama di seluruh lokasi ujian di Indonesia, telah disiapkan 62 orang penguji yang terdiri atas unsur Hakim Tinggi Agama (31 orang) dan unsur akademisi (31 orang) yang berasal dari Perguruan Tinggi. ${ }^{1}$ Tiap peserta akan diuji oleh 2 penguji, satu dari Hakim Tinggi dan satu lagi dari akademisi. Secara umum, materi seleksi wawancara ini dibagi ke dalam empat bagian; Umum, Substansi, Visi dan Misi dan Membaca Kitab Kuning. ${ }^{1}$

${ }^{1}$ Di antara PerguruanTinggi yang dilibatkan ${ }^{8}$ untuk menguji Wawancara yaitu : Universitas Indonesia Jakarta, Universitas Gajah Mada Yogyakarta, Universitas Airlangga Surabaya, Universitas Pajajaran Bandung, Universitas Diponegoro Semarang, Universitas Brawijaya Malang, Universitas Sumatera Utara Medan, Universitas Andalas Padang dan Universitas Islam Negeri Sumatera Utara Medan, Lihat Mahkamah Agung, "87 Akademisi Dari 21 Perguruan Tinggi Negeri dan 1 Perguruan Tinggi Swasta Menguji Calon Hakim," https://www.mahkamahagung.go.id/id/artikel/2747/87-akademisi-dari-21perguruan-tinggi-negeri-dan-1-perguruan-tinggi-swasta-menguji-calon-hakim, diakses tgl 18 Agustus 2018.

1 Lihat Slide Persiapan Seleksi Kompetensi Bidang Calon Hakim Mahkamah Agung Republik Indonesia, Calon Hakim Peradilan Agama Tahun 2017. 
17 Ibnu Radwan Siddik Turnip \& Amal Hayati

\section{Akseptabilitas Alumni Jurusan Ahwal Syakhsiyah Pada Seleksi Calon Hakim Peradilan Agama}

Setelah melalui tahapan Seleksi Kemampuan Dasar (SKD) dimulai tanggal 18 s/ 22 September 2017 di 30 lokasi di seluruh Indonesia, ${ }^{2}$ maka Panitia Seleksi dalam Suratnya Nomor 06/Pansel/MA/09/2017 pada tanggal 28 September 2018 mengumumkan nama-nama peserta yang lulus SKD dan berhak mengikuti seleksi selanjutnya yakni SKD. Dari 468 peserta yang lulus SKD, yang merupakan alumni Fakultas Syariah dan Hukum Universitas Islam Negeri Sumatera Utara sebanyak 9 orang.

Tabel 1

Alumni Fakultas Syari'ah dan Hukum UIN SU Yang Lulus Tes SKD

\begin{tabular}{|c|l|c|c|c|}
\hline No & \multicolumn{1}{|c|}{ Nama } & Jurusan & $\begin{array}{c}\text { Total } \\
\text { Nilai }\end{array}$ & Ranking \\
\hline 1 & Agus Adhari & A S & 364 & 24 \\
\hline 2 & Fachruddin Zakarya & A S & 353 & 48 \\
\hline 3 & $\begin{array}{l}\text { Muhammad Ilham Al } \\
\text { Firdaus Lubis }\end{array}$ & A S & 348 & 74 \\
\hline 4 & Ulya Urfa & A S & 339 & 136 \\
\hline 5 & Muhammad Idris Nst & A.S & 328 & 264 \\
\hline 6 & M Rizfan Wahyudi Al Haris & A S & 316 & 387 \\
\hline 7 & $\begin{array}{l}\text { Musad Al } \\
\text { Pulungan }\end{array}$ & PHM & 315 & 395 \\
\hline 8 & Nurhayati Hasibuan & A S & 314 & 402 \\
\hline 9 & Fauzan Arrasyid & \multicolumn{2}{|c|}{} \\
\hline
\end{tabular}

Sumber: Data sekunder yang diolah, 2018

Dari tabel di atas diketahui bahwa jumlah alumni Jurusan AS yang lulus sebanyak 7 orang, relatif jauh lebih tinggi

2 Ujian SKD dilakukan di Kantor Badan Kepegawai\&n Nasiona (BKN) yang tersebar di beberapa kota propinsi. Untuk Alumni Fakultas Syaria'ah dan Hukum UIN Sumatera Utara Mayoritas mengikuti ujian SKD di Kantor BKN Kanreg VI Medan. 
Akseptabilitas Alumni Jurusan Al-Ahwal Al-Syakhsiyah .... $\mid 18$

dibanding alumni Jurusan lain seperti Jurusan Muamalah dan PHM yang hanya masing-masing 1 orang alumni yang lulus.

Setelah mengikuti seleksi selanjutnya, yakni Seleksi Kemampuan Bidang (SKB), maka pada hari Jum'at Tanggal 3 November 2017 MahkamahAgung RI mengumumkan kelulusan Akhir Seleksi Calon Hakim di Lingkungan Mahkamah Agung RI Tahun 2017 sesuai dengan Surat Sekretaris Mahkamah Agung RI Nomor: 11/Pansel/MA/11/2017.

Untuk Peradilan Agama, Mahkamah Agung meluluskan 454 Cakim Peradilan Agama dari Formasi Umum, 62 orang dari Formasi Cumlaude dan 9 orang Formasi Putra/Putri Papua. ${ }^{2}$

Dari 468 peserta SKD Formasi Umum, yang lulus final sebanyak 454 orang, jadi ada sekitar 14 peserta yang tidak lulus. Dalam keterangan disebutkan bahwa ketidaklulusan mereka disebabkan oleh tidak bisa membaca kitab kuning (7 orang) dan tidak lengkap mengikuti SKB (7 orang).

Tabel 2

Hasil Nilai Integrasi SKD dan SKB

Alumni Fakultas Syari'ah dan Hukum UIN Sumatera Utara

\begin{tabular}{|c|l|c|c|c|c|c|}
\hline No & Nama & Jurusan & $\begin{array}{c}\text { Nilai } \\
\text { SKD } \\
\mathbf{4 0} \%\end{array}$ & $\begin{array}{c}\text { Nilai } \\
\text { SKB } \\
\mathbf{6 0} \%\end{array}$ & $\begin{array}{c}\text { Nilai } \\
\text { Akhir }\end{array}$ & Ranking \\
\hline 1 & Agus Adhari & AS & 29,04 & 39.15 & 68,19 & 22 \\
\hline 2 & Muhammad Idris Nst & AS & 26.24 & 39.60 & 65,84 & 65 \\
\hline 3 & Ulya Urfa & AS & 27.12 & 37.88 & 65.00 & 96 \\
\hline 4 & Fauzan Arrasyid & AS & 25.12 & 38.40 & 63.52 & 149 \\
\hline 5 & M Rizfan Wahyudi & M & 25.36 & 36.53 & 61.89 & 222 \\
\hline
\end{tabular}

${ }^{2}$ Lihat Lampiran Surat Menteri Pendayagunaan Aparatur Negara dan Reformasi Birokrasi selaku Ketua Tim Pengarah Panselnas Nomor B/554/S.SM.01.00/2017 tanggal 3 November 2017 tentang Hasil Nilai Integrasi SKD dan SKB Seleksi CPNS Tahun 2017 Instansi Mahkamah Agung Unit Peradilan Agama Formasi Jabatan Calon Hakim. 
19| Ibnu Radwan Siddik Turnip \& Amal Hayati

\begin{tabular}{|c|l|c|c|c|c|c|}
\hline 6 & $\begin{array}{l}\text { Muhammad Ilham Al } \\
\text { Firdaus }\end{array}$ & AS & 27,84 & 31.73 & 59,57 & 323 \\
\hline 7 & Fachruddin Zakarya & AS & 28,24 & 30,45 & 58,69 & 353 \\
\hline 8 & Nurhayati Hasibuan & PHM & 25.20 & 31,50 & 56.70 & 410 \\
\hline 9 & $\begin{array}{l}\text { Musad Al Haris } \\
\text { Pulungan }\end{array}$ & AS & 26,50 & 30,90 & 56,18 & 420 \\
\hline
\end{tabular}

Sumber: Data primer yang diolah, 2018

Dari tabel di atas terlihat bahwa untuk alumni Jurusan AS Fakultas Syari'ah UIN SU semuanya lulus dalam ujian Akhir. Demikian pula dua orang lagi yang dari Jurusan Muamalah dan PHM. Dari tabel di atas pula kita bisa melihat bahwa tingkat keberterimaan (akseptabilitas) alumni Jurusan AS dalam tes ujian Calon Hakim Peradilan Agama dalam tingkat Fakultas Syariah dan Hukum relatif sangat tinggi dibanding alumni Jurusan lainnya yakni Jurusan Muamalah dan PHM. Alumni Jurusan AS yang behasil lulus sebanyak 7 orang, sementara alumni Jurusan Muamalah dan PHM masing-masing 1 orang saja. Namun, bila kita bicara dalam level nasional sepertinya tingkat akseptabilitas alumni Jurusan AS Fakultas Syari'ah dan UIN Sumatera Utara relatif masih di bawah. Dari 454 cakim yang lulus dari Formasi Umum, hanya 7 orang saja yang lulus dari alumni AS, berarti hanya sekitar 1,5\% saja dari total cakim yang lulus secara nasional. Sementara itu, pada Jurusan AS PTIN lainnya di Indonesia, sebaran alumni yang lulus diantaranya: Jurusan AS UIN Sunan Kali Jaga (60 orang), Jurusan AS UIN Syarif Hidayatullah (46 orang), Jurusan AS UIN Malang (31 orang), Jurusan AS UIN Arraniry Banda Aceh (14 orang), Jurusan AS UIN Imam Bonjol Padang (11 orang) dan Jurusan AS UIN Banjar Masin (11 orang). ${ }^{2}$

${ }^{2}$ Data diperoleh melalui hasil wawancara Kajur Ahwal Syaksiyyah Fak. Syari'ah dan UIN SU Sumatera Utara. Amal Hayati, Ketua Jurusan AlAhwal Al-Syakhsiyah FASIH UIN SU, Wawancara Pribadi, Medan, 7 Nopember 2017

Ulul Albab: Jurnal Studi dan Penelitian Hukum Islam 
Akseptabilitas Alumni Jurusan Al-Ahwal Al-Syakhsiyah .... $\left.\right|_{20}$

\section{Faktor-Faktor Ketidaklulusan Alumni Al-Ahwal Al- Syakhsiyah}

Untuk menjawab pertanyaan ini, peneliti telah menemukan setidaknya 22 orang responden penelitian yang kesemuanya adalah alumni Jurusan Al-Ahwal Al-Syakhsiyah UIN SU yang tidak lulus SKD calon Hakim Peradilan Agama Tahun 2017 kemarin. Ada 5 faktor yang diajukan kepada responden yang menjadi penyebab ketidaklulusan alumni dalam Seleksi Kompetensi Dasar (SKD) calon Hakim Peradilan Agama Tahun 2017. Di antara faktor-faktor tersebut adalah:

\section{Materi soal-soal ujian yang cukup sulit}

Soal-soal ujian SKD diklasifikasikan ke dalam tiga bentuk tes, yakni Tes Wawasan Kebangsaan (TWK), Tes Intelegensia Umum (TIU) dan Tes Karakteristis Pribadi (TKP). Walaupun soal-soal ketiga tes ini bersifat umum, artinya belum masuk kepada soal-soal yang berhubungan dengan spesialisasi Sarjana Syari'ah atau Sarjana Hukum Islam, tetapi bisa saja soalsoal tersebut menyulitkan bagi alumni. Karena mereka harus mengingat kembali ilmu-lmu yang berhubungan dengan wawasan kebangsaan, intelegiansia umum dan karakteristik pribadi yang dulu pernah mereka dapatkan di bangku sekolah sebelum masuk jenjang pendidikan S1.

Tabel 3

Pendapat Responden Tentang Penyebab Tidak Lulus SKD Karena Soal-soal Ujian Yang Cukup Sulit

\begin{tabular}{|l|c|c|}
\hline \multicolumn{1}{|c|}{ Pendapat } & Frekuensi & Prosentase (\%) \\
\hline Setuju & 14 & 63,6 \\
\hline Tidak Setuju & 8 & 36,4 \\
\hline Total & 22 & 100 \\
\hline
\end{tabular}

Sumber: Data primer yang diolah, 2018 
21 Ibnu Radwan Siddik Turnip \& Amal Hayati

Berdasarkan tabel tersebut dapat diketahui bahwa sebagian besar responden sejumlah 14 responden $(63,6 \%)$ setuju dengan pendapat bahwa soal-soal ujian yang diberikan pada SKD cukup sulit untuk dikerjakan. Sedangkan 8 responden $(36,4 \%)$ tidak setuju dengan pendapat tersebut. Dengan demikian dapat disimpulkan bahwa soal-soal yang cukup sulit merupakan salah satu penyebab yang dirasakan para responden sehingga tidak dapat menembus passing grade (ambang batas kelulusan) yang ditentukan.

Hasil temuan penelitian menunjukkan bahwa dari ketiga jenis tes yakni TWK, TIU dan TKP, maka Tes Inteligensia Umum (TIU) merupakan tes yang paling sulit.

Tabel 4

Pendapat Responden Tentang Tes SKD yang Paling Sulit

\begin{tabular}{|c|c|c|}
\hline Jenis Tes & Frekuensi & Prosentase (\%) \\
\hline Tes Wawasan Kebangsaan & 4 & 18,2 \\
\hline Tes Intelegensia Umum & 17 & 77,3 \\
\hline Tes Karakteristik Pribadi & 1 & 4,5 \\
\hline Total & $\mathbf{2 2}$ & $\mathbf{1 0 0}$ \\
\hline
\end{tabular}

Sumber: Data primer yang diolah, 2018

Berdasarkan tabel tersebut diketahui bahwa sebahagian besar responden sejumlah 17 orang $(77,3 \%)$ berpendapat bahwa Tes Intelegensia Umum merupakan tes yang paling sulit. Sementara 4 responden $(18,2 \%)$ berpendapat bahwa Tes Wawasan Kebangsaan merupakan tes yang paling sulit, dan 1 responden $(4,5 \%)$ berpendapat Tes Karakteristik Pribadi yang paling sulit.

\section{Penggunaan sistem komputer (CAT) yang dianggap belum terbiasa (familiar)}

Pelaksanaan Seleksi Kompetensi Dasar (SKD) mempergunakan sistem komputerisasi. Proses tanya jawab 
Akseptabilitas Alumni Jurusan Al-Ahwal Al-Syakhsiyah .... $\mid 22$

peserta ujian dilaksanakan dengan menggunakan aplikasi computer yang telah disiapkan oleh Badan Kepegawaian Negara (BKN).

Tabel 5

Pendapat Responden Tentang Penyebab Tidak Lulus SKD

Karena Penggunaan Sistem Komputer (CAT) Yang Dirasa Belum

Terbiasa (familiar)

\begin{tabular}{|l|c|c|}
\hline \multicolumn{1}{|c|}{ Pendapat } & Frekuensi & Prosentase (100 \%) \\
\hline Setuju & 7 & 31,8 \\
\hline Tidak Setuju & 15 & 68,2 \\
\hline Total & 22 & 100 \\
\hline
\end{tabular}

Sumber: Data primer yang diolah, 2018

Tabel tersebut mengindikasikan bahwa 15 responden $(68,2 \%)$ tidak menjadikan penggunaan sistem komputer dalam ujian SKD sebagai penyebab ketidaklulusan, sementara 7 responden lainnya $(31,8 \%)$ setuju menjadikan hal ini sebagai salah satu penyebab ketidaklulusan. Hal ini disebabkan bisa saja karena para alumni Jurusan AS merupakan para sarjana S1 yang tentunya sudah terbiasa berinteraksi dengn komputer dalam proses belajar di perkuliahan dahulu. Tetapi walaupun demikian bila kita tidak pernah mempergunakan aplikasi tertentu pada komputer tentunya akan membutuhkan waktu untuk mempelajarinya.

\section{Waktu ujian yang relatif singkat}

Sebagaimana disebutkan sebelumnya, bahwa jumlah soal yang diberikan dalam SKD berjumlah 100 soal dengan rincian, 35 soal TWK, 30 soal TIU dan 35 soal TKP. Waktu yang diberikan untuk menyelsaikan soal-soal tersebut adalah 90 menit atau 5.400 detik. Ini artinya bila seorang peserta ingin menjawab seluruh soal, maka ia harus menjawab tiap soal dalam waktu 54 detik. Sebagian besar responden setuju bahwa waktu yang diberikan relatife singkat dengan jumlah soal yang mesti dikerjakan. 
23 Ibnu Radwan Siddik Turnip \& Amal Hayati

Tabel 6

Pendapat Responden Tentang Penyebab Tidak Lulus SKD

Karena Waktu Ujian Yang Relatif Singkat

\begin{tabular}{|l|c|c|}
\hline \multicolumn{1}{|c|}{ Pendapat } & Frekuensi & Prosentase (100\%) \\
\hline Setuju & 15 & 68,2 \\
\hline Tidak Setuju & 7 & 31,8 \\
\hline Total & 22 & 100 \\
\hline
\end{tabular}

Sumber: Data primer yang diolah, 2018

Dari tabel tersebut dapat diketahui bahwa sebagian besar responden, sejumlah 15 responden $(68,2 \%)$ setuju bahwa waktu yang diberikan dalam SKD relative singkat dalam menjawab 100 soal yang diberikan. Hal ini juga menjadi salah satu penyebab tidak mampunya mereka dalam menembus angka ambang batas yang ditentukan. Sementara 7 responden lagi (31,8\%) tidak setuju bila dikatakan waktu yang diberikan relatif singkat.

Sebenarnya bila peserta ujian sebelumnya sering melakukan latihan (simulasi) dalam menyelesaikan soa-soal tes CPNS dengan menggunakan sistem CAT ini, maka mereka akan terbiasa dengan menjawab soal-soal ujian dalam waktu yang relatif singkat. Karena dapat menjawab soal-soal dengan cepat juga merupakan salah satu bentuk dari cirri ujian SKD ini.

Hasil penelitian juga menunjukkan bahwa sebagian besar responden memang tidak pernah melakukan latihan (simulasi) ujian dengan menggunakan sistem CAT.

\section{Angka passing grade kelulusan yang cukup tinggi}

Sesuai dengan pasal 2 PP MenPAN dan RB Nomor 22 Tahun 2017, angka passing grade SKD untuk TWK adalah 75, angka TIU adalah 80 dan angka untuk TKP adalah 143. Jadi seorang CPNS harus mendapatkan score 298 dari ketiga jenis tes tersebut dengan catatan tidak ada salah satu dari jenis tes tersebut yang nilainya dibawah passing grade. Artinya walaupun seseorang mendapat nilai 298 secara keseluruhan tetapi nilai TIU misalnya tidak sampai 80, maka ia tidak lulus passing grade SKD. 
Akseptabilitas Alumni Jurusan Al-Ahwal Al-Syakhsiyah .... $\mid 24$

Ketentuan angka passing grade ini dirasakan oleh sebagian besar responden cukup tinggi untuk dicapai.

Tabel 7

Pendapat Responden Tentang Penyebab Tidak Lulus SKD

Karena Angka Passing Grade Kelulusan Yang Cukup Tinggi

\begin{tabular}{|l|c|c|}
\hline \multicolumn{1}{|c|}{ Pendapat } & Frekuensi & Prosentase (100\%) \\
\hline Setuju & 14 & 63,6 \\
\hline Tidak Setuju & 8 & 36,4 \\
\hline Total & 22 & 100 \\
\hline
\end{tabular}

Sumber: Data primer yang diolah, 2018

Dari tabel tersebut menunjukkan bahwa sebagian besar responden, yakni 14 responden $(63,6 \%)$ setuju dengan pendapat bahwa salah satu faktor ketidaklulusan alumni dalam SKD adalah karena angka passing grade yang cukup tinggi. Sementara 8 responden lainnya (36,4\%) tidak setuju bila angka passing grade kelulusan dijadikan salah satu faktor ketidak lulusan para alumni.

\section{Lebih fokus pada persiapan Seleksi Kemampuan Bidang (SKB)}

Menjadi seorang hakim Peradilan Agama tentunya mesti menguasai ilmu hukum baik yang berkenaan dengan hukum materil maupun hukum acara, hukum umum dan juga hukum Islam (fiqh) tentunya. Satu hal lagi seorang calon Hakim Peradilan Agama dituntut untuk mampu membaca dan memahami kitab kuning (kitab-kitab fikih klasik). Kemampuan membaca kitab ini menjadi bagian dari tes SKB nantinya bila seseorang lolos dari SKD. Mengingat begitu banyak materimateri ilmu hukum yang mesti dipelajari lagi dan mengasah kemampuan membaca kitab kuning sebagai persiapan SKB, membuat sebagian responden lebih fokus dalam mempersiapkan diri menghadapi tes SKB dibanding tes SKD. 
25 Ibnu Radwan Siddik Turnip \& Amal Hayati

Mereka lupa bahwa bila tidak lulus SKD maka tidak akan bisa mengikuti tes SKB.

Tabel 8

Pendapat Responden Tentang Penyebab Tidak Lulus SKD

Karena Lebih Fokus Pada Persiapan SKB

\begin{tabular}{|l|c|c|}
\hline \multicolumn{1}{|c|}{ Pendapat } & Frekuensi & Prosentase (100\%) \\
\hline Setuju & 16 & 72,7 \\
\hline Tidak setuju & 6 & 27,3 \\
\hline Total & 22 & 100 \\
\hline
\end{tabular}

Sumber: Data yang diolah, 2018

Dari tabel tersebut menunjukkan bahwa sebagian besar responden yakni 16 responden $(72,7 \%)$ setuju bahwa mereka lebih fokus mempersiapkan diri dalam menghadapi SKB daripada SKD, sementara 6 responden lainnya $(27,3 \%)$ tidak setuju. Berdasarkan hasil prosentase yang cukup signifikan ini, kita bisa menyimpulkan bahwa ada hubungan yang erat antara lebih fokusnya alumni kepada persiapan SKB daripada SKD menjadi salah satu penyebab ketidaklulusan mereka dalam tes SKD.

\section{Pembahasan}

Hasil penelitian di atas menunjukkan bahwa akseptabilitas alumni Jurusan Al-Ahwal Al-Syakhsiyah (AS) dalam tingkat Fakultas relatif jauh lebih tinggi dibanding alumni Jurasan lain yang ada pada Fakultas Syari'ah dan Hukum UIN Sumatera Uatara. Alumni Jurusan AS yang lulus 7 orang dari 454 calon Hakim Peradilan Agama dari Formasi Umum. Kelulusan alumni AS ini mencapai 1,5\% dari total cakim yang lulus secara nasional. Sementara alumni Jurusan PHM dan Muamalah hanya meluluskan 1 alumninya, atau 0,2\% dari cakim yang lulus secara nasional. 
Akseptabilitas Alumni Jurusan Al-Ahwal Al-Syakhsiyah .... $\left.\right|_{26}$

Akan tetapi bila akseptabilitas alumni AS Fakultas Syari'ah dan Hukum UIN Sumatera Utara ini dibandingkan dengan alumni Jurusan AS ada Perguruan Tinggi Islam Negeri lainnya di Indonesia, maka capain 1,5\% tersebut masih di bawah lagi. Hasil penelitian menunjukkan bahwa capaian alumni Jurusan AS UIN Sunan Kalijaga yang lulus mencapai 60 orang $(13,2 \%)$, alumni Jurusan AS UIN Syarif Hidayatullah yang lulus 46 orang $(10,1 \%)$, alumni Jurusan AS UIN Sunan Ampel yang lulus 43 orang $(9,4 \%)$, alumni Jurusan AS UIN Malang yang lulus 31 orang $(6,8 \%)$, alumni Jurusan AS UIN Arraniry Banda Aceh yang lulus 14 orang (3,08\%) dan alumni Jurusan AS UIN Imam Bonjol Padang yang lulus 11 orang $(2,4 \%)$.

Hasil penelitian juga menunjukkan bahwa banyaknya alumni AS yang lulus menjadi calon Hakim Peradilan Agama karena tidak lulus dalam passing grade Seleksi Kompetensi Dasar (SKD) yang terdiri dari Tes Wawasan Kebangsaaan (TWK), Tes Intelegensia Umum (TIU) dan Tes Karakteristik Pribadi (TKP). Faktor-faktor yang dominan yang dialami para alumni AS sehingga gagal dalam SKD berdasarkan 22 responden dapat diklasifikasikan dalam tabel berikut.

Tabel 9

Faktor-Faktor Dominan Yang Menyebabkan Ketidaklulusan dalam SKD

\begin{tabular}{|c|l|c|c|}
\hline No & \multicolumn{1}{|c|}{ Faktor Dominan } & Frekuensi & Prosentase \\
\hline 1 & Lebih Fokus Pada Persiapan SKB & 16 & 72,7 \\
\hline 2 & Waktu ujian yang relatif singkat & 15 & 68,2 \\
\hline 3 & Soal-soal ujian SKD yang cukup sulit & 14 & 63,6 \\
\hline 4 & $\begin{array}{l}\text { Angka Passing Grade Kelulusan Yang } \\
\text { Cukup Tinggi }\end{array}$ & 14 & 63,6 \\
\hline 5 & $\begin{array}{l}\text { Penggunaan sistem komputer (CAT) } \\
\text { yang dianggap belum terbiasa } \\
\text { (familiar) }\end{array}$ & 7 & 31,8 \\
\hline
\end{tabular}

Sumber: Data primer yang diolah, 2018 
27 Ibnu Radwan Siddik Turnip \& Amal Hayati

Tabel di atas menjelaskan bahwa faktor-faktor yang menyebabkan ketidaklulusan alumni AS pada SKD yang pertama adalah karena mereka lebih fokus dalam mempersiapkan ujian SKB yang dianggap lebih sulit daripada SKD. Responden yang menyetujui faktor ini mencapai 72,7 \%. Kedua adalah faktor waktu ujian yang diberikan kepada peserta ujian SKD relatif singkat untuk menjawab soal-soal yang berhubungan dengan kompetensi dasar seperti TWK, TIU dan TKP. Responden yang menyetujui faktor ini mencapai $68,2 \%$. Ketiga adalah faktor bahwa soal-soal SKD yang diberikan cukup sulit untuk dijawab terlebih soal-soal yang berhubungan dengan TIU dan TKP. Responden yang menyetujui faktor ini mencapai $63,6 \%$. Keempat adalah faktor bahwa angka passing grade SKD cukup tinggi. faktor ini disetujui oleh $63,6 \%$ responden. Yang kelima adalah faktor penggunaan sistem computer (CAT) dalam ujian SKD yang belum terbiasa bagi para alumni. Responden yang menyetujui faktor ini hanya mencapai $31,8 \%$, jadi tidak begitu signifikan dibanding dengan faktor-faktor lainnya.

Seleksi Calon Hakim Peradilan Agama merupakan salah satu seleksi CPNS sebagaimana yang dilaksanakan pada instansi-instansi pemerintah lainnya. Berdasarkan Keputusan Menteri Pendayagunaan Aparatur Negara dan Reformasi Birokrasi Nomor 29 Tahun 2017 Tentang Kebutuhan Pegawai Aparatur Sipil Negara Calon Hakim Di Lingkungan Mahkamah Agung Tahun Anggaran 2017, Mahkamah Agung akan melakukan rekrut mencalon Hakim melalui jalur CPNS dengan status Calon Hakim. Oleh karena direkrut melalui CPNS, maka berlakulah Undang Undang Nomor 5 Tahun 2014 Tentang Aparatur Sipil Negara dan Peraturan Pemerintah Nomor 11 Tahun 2017 Tentang Menejemen Pegawai Negeri Sipil serta Peraturan Menteri Pendayagunaan Aparatur Negara dan Reformasi Birokrasi Republik Indonesia Nomor 20 Tahun 2017 Tentang Kriteria Penetapan Kebutuhan Pegawai Negeri Sipil 
Akseptabilitas Alumni Jurusan Al-Ahwal Al-Syakhsiyah .... $\left.\right|_{28}$

dan Pelaksanaan Seleksi Calon Pegawai Negeri Sipil Tahun 2017..$^{2}$

Ketentuan Seleksi Kompetensi Dasar (SKD) merupakan bagian dari peraturan perekrutan CPNS yang berlaku pada semua instansi pemerintah. Setelah lulus SKD barulah materimateri yang berhubungan dengan formasi jabatan yang hendak kita pilih akan diberikan pada Seleksi Kompetensi Bidang (SKB). Jadi, seyogyanya para alumni harus jeli dalam mengatur strategi dalam menghadapi seleksi Calon Hakim Peradilan Agama. semestinya mereka fokus dulu dalam membahas soal-soal yang berhubungan dengan SKD yang biasanya merupakan pelajaran umum yang didapat semenjak duduk di bangku SD, MIN, SMP, MTsN, SMA dan MAN dahulu seperti Pancasila, UUD 1945, Matematika dasar dan Bahasa Indonesia. Salah seorang alumni yang lulus, Fakhruddin Zakarya, mengemukakan pengalamannya bahwa beliau lebih fokus membaca buku-buku yang berkaitan dengan Tes Potensi Akademik, buku-buku Sejarah Indonesia, Pancasila dan UUd 1945 ketika menghadapi tes SKD. Untuk menghadapi seleksi bidang, belakangan dipikirkan. ${ }^{2}$ Pengalaman Agus Adhari, alumni yang lulus, juga hampir sama. Kemampuanya dalam menaklukkan SKD dikarenakan telah terbiasanya beliau dalam membaca dan memahami tes yang hampir sama seperti Tes Potensi Akademik dalam ujian-ujian penerimaan bea siswa atau pendidikan S2. Kebiasaan ini sangat membantunya dalam menyelesaikan soalsoal SKD. Dalam rangking nasional pun, beliau menduduki rangking 24, tertinggi dari semua alumni Jurusan AS Fakultas

2 Abdullah, "Rekrutmen Calon Hakim Tahun Anggaran 2017," https://www.mahkamahagung.go.id/id/artikel/2623/rekrutmen-calon-hakim-tahunanggaran-2017, diakses tanggal 18 Agustus 2018.

2 Dari rangking nasional yang lulus SKD Fachrutddin Zakarya ini menempati rangking ke 48 (sangat bagus), walaupun pada setelah tes SKB, akhirnya beliau mendapat rangking 353 . 
29 Ibnu Radwan Siddik Turnip \& Amal Hayati

Syari'ah dan Hukum UIN SU yang lulus pada ujian SKD tersebut. ${ }^{2}$

Adapun mengenai format ujian SKD yang dirasa cukup sulit, waktu yang relatif sedikit, angka passing grade yang cukup tinggi dan penggunaan sistem CAT dalam ujian, sehingga menjadi bagian dari faktor ketidaklulusan alumni, harus disikapi dengan objektif dan proporsional. Menjadi Hakim Peradilan Agama memang merupakan sesuatu yang prestesius. Ketua Mahkamah Agung Republik Indonesia, dalam pengarahan dan amanatnya terkait rekrutmen Hakim ini menekankan, bahwa seleksi Calon Hakim harus dilaksanakan secara obyektif, transparan dan akuntabel dan dimaksudkan untuk memperoleh Calon Hakim yang berkualitas dan berintegritas tinggi. Dalam rangka menjamin obyektivitas, transparansi dan akuntabilitas serta memperoleh sumber daya Hakim yang berkualitas dan berintegritas tersebut, Mahkamah Agung dalam melakukan rekrutmen tidak akan melakukan sendiri, melainkan menyerahkan sepenuhnya kepada Kementerian PAN \& RB dan Badan Kepegawaian Negara. ${ }^{2}$

Penggunaan sistem CAT dalam perekrutan CPNS dinilai sangat ampuh untuk mengatasi praktek Korupsi Kolusi dan Nepotisme (KKN). Seorang peserta ujian bisa langsung tahu nilainya melalui layar komputer ketika selesai ujian SKD, apakah ia lulus passing grade atau tidak. Sekretaris Mahkamah Agung, Achmad Setyo Pudjoharsoyo, memastikan proses seleksi calon hakim dilakukan transparan dan akuntabel. Proses tersebut juga menghindari tindak korupsi, kolusi, dan nepotisme. Bahkan, tidak sedikit anak pejabat MA yang gugur dalam seleksi karena tidak memenuhi kualifikasi. "Hampir semua anak-anak pejabat di MA justru tidak lolos. Bukan karena

2 Agus Adhari, Alumni Jurusan AS, Wawancara Pri̊badi, Medan, 19 Oktober 2018.

2 Abdullah, ibid.

Ulul Albab: Jurnal Studi dan Penelitian Hukum Islam 
Akseptabilitas Alumni Jurusan Al-Ahwal Al-Syakhsiyah .... $\mid 30$

tidak kami loloskan, secara kualitas, anak peserta tidak lolos seleksi calon hakim," ujar Achmad dalam diskusi publik bertajuk "Mendukung Pengadilan yang Transparan dan Akuntabel" di Universitas Padjajaran, Bandung, Rabu (25/10/2017). "Termasuk anak saya sendiri tidak lolos," kata dia. Achmad mengatakan, MA berkomitmen untuk melakukan proses seleksi yang transparan agar hakim yang disaring benar-benar berkualitas. Hal ini tidak terlepas dari harapan masyarakat untuk mewujudkan badan peradilan yang betul-betul dipercaya. ${ }^{2}$

Akan tetapi, rendahnya capaian kuota yang lulus SKD secara nasional, termasuk para alumni Jurusan AS Fakultas Syari'ah dan Hukum UIN SU, setidaknya bisa menjadi bahan pertimbangan bagi Mahkamah Agung. Di satu sisi kita menginginkan seleksi Calon Hakim Peradilan Agama yang bersih dan memahami materi SKD secara baik, tetapi di sisi lain, Calon Hakim Peradilan Agama juga harus kompeten dalam ilmu bidangnya seperti ilmu-ilmu hukum Islam dan membaca Kitab Kuning. Sebab dalam memutuskan perkara nantinya para Hakim Peradilan Agama dituntut untuk merujuk kepada kitabkitab fikih yang sebagian besar masih menggunakan literatur Bahasa Arab gundul atau Kitab Kuning. Banyak dari alumni Jurusan AS yang tidak lulus SKD sementara kemampuan bidangnya dan kemampuan membaca Kitab Kuning sangat kompeten. $^{2}$ Hal ini menjadi ironi, sebab sebelum påra alumni disuguhkan dengan ujian yang berhubungan dengan bidang keahlian mereka seperti ujian tulis materi hukum, wawancara

2 "Banyak Anak Pejabat MA Yang Tidak Lolos Seleksi Calon Hakim” Kompas.Com, https://nasional.kompas.com/read/2017/10/25/14292671/banyakanak-pejabat-ma-yang-tak-lolos-seleksi-calon-hakim, diakses tanggal 23 Oktober 2018.

2 Kita bisa melihat dari 22 responden Alumri AS, 14 orang merupakan lulusan dengan IPK Sangat memuaskan, di atas 3,5. Artinya kemampuan mereka dalam memahami dan menguasai materi ilmu hukum umum dan hukum Islam, sebagaimana telah dipaparkan pada sebaran mata kuliah Jurusan AS pada bab sebelumnya, bisa dikatakan sangat berkompeten. 
31 Ibnu Radwan Siddik Turnip \& Amal Hayati

seputar pengetahuan Peradilan Agama dan membaca kitab fikih klasik (qiraat kutub), mereka sudah gugur dulu dalam ujian berkenaan dengan wawasan kebangsaan, intelegensi umum dan karakteristik pribadi. Di sisi lain, karena kualifikasi sarjana yang dibutuhkan menjadi Calon Hakim Peradilan Agama ini juga mengikutsertakan alumni Sarjana Hukum, maka sedikit ada ketimpangan. Banyak di antara mereka (Sarjana Hukum) yang lulus SKD, karena memang soal-soalnya berhubungan dengan kemampuan dasar keilmuan, tetapi kemampuan bidang hukum Islam dan membaca Kitab Kuningnya kurang kompeten.

Dalam hasil ujian akhir, yakni hasil integrasi nilai SKD dan SKB, terdapat 7 orang cakim yang tidak lulus dengan keterangan tidak dapat membaca Kitab Kuning. Kiranya perimbangan antara Calon Hakim Peradilan Agama yang berasal dan Sarjana Syari'ah atau Sarjana Hukum Islam dengan Sarjana Hukum mesti menjadi bahan pertimbangan dalam perekrutan calon Hakim Peradilan Agama ke depannya. Di satu sisi Sarjana Syari'ah atau Sarjana Hukum Islam hanya boleh mengikuti seleksi Calon Hakim Peradilan Agama saja, sementara di sisi lain Sarjana Hukum boleh mengikuti seleksi Calon Hakim di Peradilan Agama, Peradilan Umum dan Peradilan Tata Usaha Negara. Setidaknya standar soal-soal yang berhubungan dengan Kemampuan Dasar dan angka passing grade yang dinilai cukup tinggi bagi alumni Jurusan AS, bisa menjadi bahan masukan bagi Mahkamah Agung. Bisa saja dibedakan standarnya dan angka passing gradenya antara alumni Sarjana Syari'ah atau Sarjana Hukum Islam dengan mereka yang berasal dari Sarjana Hukum.

Relatif rendahnya akseptabilitas alumni Jurusan AS Fakultas Syari'ah dan Hukum UIN Sumataera Utara pada penerimaan calon Hakim Peradilan Agama di Mahakamah Agung Tahun 2017 tentunya menjadi tantangan sendiri bagi pihak Fakultas Syari'ah dan Hukum secara umum dan secara khusus bagi pihak-pihak yang terlibat dalam proses belajar dan 
Akseptabilitas Alumni Jurusan Al-Ahwal Al-Syakhsiyah .... $\left.\right|_{32}$

mengajar di Jurusan AS. Pertanyaannya adalah langkah-langkah apa saja yang telah dilakukan pihak Fakultas dan Jurusan AS untuk membekali para alumninya dalam menghadapi tes Cakim Peradilan Agama. Apa saja solusi yang bisa diberikan dalam mengatasi rendahnya akseptabilitas alumni AS pada tes Cakim tersebut. Untuk lebih menelusuri lebih dalam lagi tentang masalah penelitian ini, maka peneliti telah mengadakan Focus Group Discussion (FGD) pada tanggal 22 September 2018. Tujuan dari FGD ini adalah guna mencari data penelitian yang mungkin terlewatkan atau ada hal-hal yang baru yang dapat menjadikan penelitian ini lebih komorehensif.

FGD yang dilaksanakan dengan menghadirkan beragam peserta diskusi seperti unsur pimpinan Fakultas (Dekan), unsur pimpinan Jurusan AS (Sekretaris Jurusan), unsure dosen-dosen AS, Hakim Peradilan Agama dalam hal ini Bapak Drs. Bakti Ritonga, SH, MH (Ketua Pengadilan Agama Rantau Parapat), Alumni Jurusan AS yang mengikuti seleksi Calon Hakim Perdailan Agama dan para mahasiswa AS yang masih aktif.

Dekan Fakultas Syari'ah dan Hukum UIN Sumatera Utara, Dr. Zulham, MHum, dalam pemaparannya menjelaskan bahwa fenomena sedikitnya alumni Fakultas Syari'ah dan Hukum yang lulus (9 orang) merupakan masalah yang cukup serius bila dibandingkan dengan jumlah peserta yang lulus secara nasional yakni 454 orang. Sepertinya ada ketidaksesuaian/ketidakcocokan antara jumlah penerimaan mahasiswa Fakultas Syariah dan Hukum, khususnya mahasiswa Jurusan AS dengan out put kelulusan cakim Peradilan Agama tahun 2017. Untuk itu, Fakultas Syari'ah dan Hukum UIN SU melakukan tindakan percepatan dengan melaksanakan langkah-langkah sebagai berikut: ${ }^{2}$

2 Data primer yang diolah dari pemaparan pendapåt Zulham, Dekan Fak. Syari'ah dan Hukum UIN SU pada acara Focus Group Discussion (FGD) di gedung Aceh Corner Medan, 22 September 2018. 
33 Ibnu Radwan Siddik Turnip \& Amal Hayati

1. Melakukan kerjasama dengan Mahakamah Agung dalam hal ini Pengadilan Tinggi Agama (PTA) Medan untuk melaksanakan try out atau pelatihan persiapan ujian cakim Peradilan Agama pada tahun 2018. Sebenarnya sudah ada 40 orang alumni yang medaftar, tetapi karena ada persoalan kesalahan komunikasi pihak PTA Medan akhirnya membatalkan pelatihan ini. Ke depannya pihak Fakultas akan mencoba membuat negoisasi ulang.

2. Memaksimalkan pelaksanaan Peradilan Semu di Fakultas Syari'ah dan Hukum. Upaya ini diawali dengan membangun gedung peradilan semu yang representatif. Gedung ini sudah dibangun dan sangat layak untuk dijadikan praktik peradilan semu bagi mahasiswa. Sebelumnya, tidak ada gedung laboratorium peradilan semu, biasanya mahasiswa praktik dengan menumpang pada ruang sidang munaqasyah. Dengan adanya laboratorium Peradilan Semu yang layak, akan memudahkan kerjasama dengan lembaga-lembaga terkait seperti lembaga Clinical Legal Education yang ada di Universitas Indonesia, UNPAD, UGM dan USU. Pada akhirnya nanti, setiap mahasiswa wajib memiliki sertifikat lulus Peradilan Semu, walau non-sks.

Kesulitan pelaksanaan praktek Peradilan Semu dengan maksimal selama ini adalah bahwa raw material (bahan baku) mahasiswa baru yang masuk ke Fakultas Syari'ah dan Hukum memiliki standar yang berbeda-beda kemampuannya. Sebagian mereka dari alumni MAN, MAS, SMAN, SMA Swasta, SMK dan Pondok Pesantren. Sehingga mahasiswa banyak diberikan praktek-praktek ilmu dasar seperti praktek ibadah, tahsin alQur'an dan lain-lain. Ini mempengaruhi pelaksanaan praktek Peradilan Semu secara maksimal karena harus memikirkan praktek-praktek lainnya.

Drs Bakti Ritonga, SH, MH, Ketua PA Rantau Parapat dalam paparannya menjelaskan sebaiknya ketika mahasiswa sudah pada semester akhir didata siapa saja yang minat menjadi 
Akseptabilitas Alumni Jurusan Al-Ahwal Al-Syakhsiyah .... $\mid 34$

hakim Peradilan Agama lalu dibuat group diskusi dengan mempersiapkan hal-hal yang berhubungan dengan persiapan tes cakim. Pemberian materi-materi tes, try out dan informasi dari jaringan alumni Jurusan AS yang telah menjadi hakim Peradilan Agama sangat dibutuhkan. Perkembangan PA sekarang menuntut mahasiswa tidak hanya menguasai ilmu hukum Islam tradisional tetapi juga ilmu hukum umum yang berhubungan dengan teori-teori hukum, hukum acara peradilan dan perkembangan yurisprudensi hukum yang dinamis. Untuk itu kurikulum jurusan harus menyesuaikannya dengan baik. Kemudian penguatan kepada kemampuan membaca kitab-kitab fikih klasik (turas) juga mesti dilakukan. Sebagai contoh, mata kuliah fikih ibadah, fikih munakahat, fikih mawaris, hendaknya menggnakan kitab-kitab fikih klasik sebagai buku pegangannya seperti al-Muhally, Bidayah al-Mujtahid dan lain-lain.. ${ }^{3}$

Sementara dari pimpinan Jurusan AS, Irwan MAg, menjelaskan sebenarnya kurikulum AS telah mengalami perbaikan-perbaikan guna mendukung capaian profil utama Jurusan AS yaitu menjadi Hakim Peradilan Agama. Di antara mata kuliah yang dianggap mendukung bagi alumni dalam pencapaian menjadi hakim Peradlan Agama adalah mata kuliah Pengantar Ilmu Hukum, Hukum Perdata, Hukum Pidana, Hukum Perdata Islam di Indonesia, Hukum Acara Peradilan Agama, Hukum Acara Perdata, Hukum Acara Pidana, Hukum Keluarga di Dunia Islam, Kapita Selekta Peradilan Agama, Kapita Selekta Hukum Keluarga dan Administrasi Peradilan Agama. Namun demikian masih perlu adanya studi banding dengan Jurusan AS lainnya yang di PTKIN di Indonesia guna memperoleh kurikulum yang lebih baik dan menyesuaikan dengan perubahan masyarakat dan memenuhi harapan

3 Data primer yang diolah dari pemaparan pendaßat Bakti Ritonga, Ketua Pengadilan Agama Rantau Parapat pada acara Focus Group Discussion (FGD) di gedung Aceh Corner Medan, 22 September 2018. 
35 Ibnu Radwan Siddik Turnip \& Amal Hayati

Peradilan Agama dalam mendapatkan hakim-hakim yang berkompeten. Karena bagaimanapun sarjana Syari'ah dan Hukum merupakan sumber dari calon hakim Peradilan Agama. $^{3}$

Hasbullah Ja'far MA, Dosen AS, penguatan kemampuan Bahasa Arab di kelas juga mesti diperhatikan. Beliau mendapati kemampuan Bahasa Arab tiap kelas kadang memprihatinkan sekali, paling hanya 3 atau 4 orang yang mahir dalam membaca teks Kitab Kuning. Pemberian mata kuliah remedial membaca Kitab Kuning dengan kontiniu denga sistem yang praktis dan cepat diharapkan akan mendongkrak kemampuan baca Kitab Kuning mahasiswa. Karena bagaimanapun, untuk menjadi Hakim Peradilan Agama mesti mampu membaca Kitab Kuning. ${ }^{3}$

Hikmatiar Harahap SH, alumni yang tidak lulus dalam tes calon Hakim Peradilan Agama, berpendapat bahwa banyak di antara alumni dalam mengikuti tes CPNS cakim Peradilan Agama hanya niat coba-coba saja, padahal alumni Sarjana Hukum dari Universitas lain seperti Universitas Sumatera Utara, telah mempersiapkan diri jauh hari sebelumnya dengan mengikuti bimbingan belajar CPNS. Kemudian beliau juga mengeluhkan bahwa tidak ada mata kuliah di AS yang menyentuh langsung dengan tes SKD khususnya Tes Intelegensia Umum. ${ }^{3}$

3 Data primer yang diolah dari pemaparan pendapat Irwan, Sekretaris Jurusan AS Fakultas Syari'ah dan Hukum UIN Sumatera Utara, pada acara Focus Group Discussion (FGD) di gedung Aceh Corner Medan, 22 September 2018

3 Data primer yang diolah dari pemaparan peñapat Hasbullah Ja'far, Dosen Jurusan AS Fakultas Syari'ah dan Hukum UIN Sumatera Utara, pada acara Focus Group Discussion (FGD) di gedung Aceh Corner Medan, 22 September 2018

3 Data primer yang diolah dari pemaparan pendapat Hikmatiar SH, Alumni Jurusan AS Fakultas Syari'ah dan Hukum UIN Sumatera Utara, pada

Ulul Albab: Jurnal Studi dan Penelitian Hukum Islam 
Akseptabilitas Alumni Jurusan Al-Ahwal Al-Syakhsiyah .... $\mid 36$

Martaon SH, alumni Jurusan AS, juga mengimbuhkan bahwa pengajaran mata kuliah yang berhubungan dengan soalsoal SKD seperti mata kuliah Pancasila perlu diperdalam lagi di kelas. Sementara Iqbal Rasyd, Alumni Jurusan AS, mengatakan praktek Peradilan Semu harus dilaksanakan dengan maksimal tidak hanya dalam pembahasan teori-teori saja tanpa dilaksanakan prakteknya. ${ }^{3}$

Menanggapi hal ini, Dekan Fakultas Syari'ah dan Hukum, menyebutkan memang pelajaran matematika tidak diajarkan di Fakultas Syari'ah dan Hukum, maka mahasiswa mesti mengikuti try out dan bimbingan belajar menghadapi tes CPNS di luar kampus. Tetapi Dekan berusaha mengakomodir usul-usul dari alumni dengan mencanangkan try out bagi semua mahasiswa yang akan selesai di Fakultas Syariah dan Hukum dengan bekerjasama dengan BKN Kanred VI Medan. Kemudian beliau juga menanggapi bahwa penguatan mata kuliah Pancasila dan ilmu hukum lainnya mesti dilakukan dengan maksimal sebagai langkah yang konkrit dalam mempersiapkan alumni pada tes cakim Peradilan Agama pada tahun akan datang.

Dari hasil FGD, tampaknya semua peserta yang hadir sepakat bahwa seleksi menjadi Hakim Peradilan Agama pada tahun 2017 kemarin adalah merupakan peluang emas bagi alumni Fakultas Syari'ah dan Hukum pada umumnya, dan alumni Jurusan Al-Ahwal Al-Syakhsiyah pada khususnya. Untuk itu perlu diadakan langkah-langkah yang konkrit dalam mensikapi fenomena ketidaklulusan alumni AS tersebut. Pihak Fakultas dan Jurusan, sebenarnya telah memberikan pembekalan kepada mahasiswa lewat kurikulum dan praktek-

acara Focus Group Discussion (FGD) di gedung Aceh Corner Medan, 22 September 2018

${ }^{3}$ Data primer yang diolah dari pemaparan pendapat Martaon dan Iqbal Rasyd, Alumni Jurusan AS Fakultas Syari'ah dan Hukum UIN Sumatera Utara, pada acara Focus Group Discussion (FGD) di gedung Aceh Corner Medan, 22 September 2018 
37 Ibnu Radwan Siddik Turnip \& Amal Hayati

praktek peradilan. Akan tetapi, langkah-langkah ini mesti lebih diperkuat lagi dengan adanya upaya untuk membuat kelompokkelompok study bagi mahasiswa yang minat menjadi Hakim denga memberikan course berkaitan tentang pembekalan masuk CPNS Hakim Peradilan Agama. try out tes SKD dan SKB dengan bekerjasama dengan BKN juga merupakan satu solusi yang bernas. Mahasiswa sebelum tamat dari Fakultas, bisa mengukur tinggak akseptabiltasnya bila mengikuti ujian CPNS dengan melakukan try out tersebut. Penguatan mata kuliah Pancasila, kewarganegaraan, ilmu hukum umum dan kemampuan membaca Kitab Kuning bagi mahasiswa, juga merupakan tambahan solusi yang mesti dilakukan.

\section{Penutup}

Hasil penelitian menunjukkan bahwa akseptabilitas alumni Jurusan Al-Ahwal Al-Syakhsiyah (AS) dalam tingkat Fakultas relatif jauh lebih tinggi dibanding alumni Jurasan lain yang ada pada Fakultas Syari'ah dan Hukum UIN Sumatera Uatara. Alumni Jurusan AS yang lulus 7 orang dari 454 calon Hakim Peradilan Agama dari Formasi Umum. Kelulusan alumni AS ini mencapai 1,5\% dari total cakim yang lulus secara nasional. Sementara alumni Jurusan PHM dan Muamalah hanya meluluskan 1 alumninya, atau 0,2\% dari cakim yang lulus secara nasional. Akan tetapi bila akseptabilitas alumni AS Fakultas Syari'ah dan Hukum UIN Sumatera Utara ini dibandingkan dengan alumni Jurusan AS ada Perguruan Tinggi Islam Negeri lainnya di Indonesia, maka capain 1,5\% tersebut masih di bawah lagi.

Setidaknya ada 5 faktor yang menyebabkan ketidaklulusan alumni AS pada Seleksi Kompetensi Dasar (SKD). Pertama, karena para alumni lebih fokus dalam mempersiapkan Seleksi Kemampuan Bidang (SKB) yang dianggap lebih sulit daripada SKD. Kedua, faktor waktu ujian yang diberikan kepada peserta ujian SKD relatif singkat untuk 
Akseptabilitas Alumni Jurusan Al-Ahwal Al-Syakhsiyah .... $\mid 38$

menjawab soal-soal yang berhubungan dengan kompetensi dasar seperti TWK, TIU dan TKP. Ketiga, faktor bahwa soal-soal SKD yang diberikan cukup sulit untuk dijawab terlebih soal-soal yang berhubungan dengan TIU dan TKP. Keempat, faktor bahwa angka passing grade SKD cukup tinggi. Kelima, faktor penggunaan sistem computer (CAT) dalam ujian SKD yang belum terbiasa bagi para alumni.

Di antara solusi yang dapat diberikan dalam meningkatkan akseptabilitas alumni Jurusan Al-Ahwal AlSyakhsiyah pada seleksi Hakim Peradilan Agama di Mahkamah Agung adalah pembenahan praktek Peradilan Semu di Fakultas dengan menyediakan gedung laboratorium yang layak dan kondusif dan menjalin kerjasama dengan lembaga-lembaga terkait seperti lembaga Clinical Legal Education yang ada di Universitas Indonesia, pembentukan kelompok-kelompok studi pada mahasiswa yang sudah duduk di semester akhir, memberikan kesempatan kepada mahasiswa Jurusan AS sebelum tamat dari Fakultas untuk melakukan try out ujian SKD dan SKB dan memberikan motivasi kepada alumni Jurusan AS untuk mengikuti bimbingan belajar di luar kampus yang khusus sebagai persiapan mengikuti Seleksi SKD dengan sistem CAT.

\section{Daftar Pustaka}

\section{Buku}

Akmaluddin, 2008. Hukum Acara Perdata Panduan Praktis Beracara di Pengadilan, Medan: Wal Ashri Publishing.

Arto, Mukti. 2008. Praktek Perkara Perdata Pada Pengadilan Agama, Yokyakarta: Pustaka Pelajar.

Broto. Wisnu. 1997. Hakim Dan Peradilan Di Indonesia (Dalam Beberapa Aspek Kajian), Yogyakarta: Universitas Atma Jaya.

Fauzi, Achmad. 2008. 'Tanggungjawab Akademis Fakultas Syariah Dalam Perspektif UU No. 3 Tahun 2006', Al- 
39| Ibnu Radwan Siddik Turnip \& Amal Hayati

Mawarid, Vol. 18. Yogyakarta: Jurusan Syari'ah Fakultas Agama Islam UII.161-172.

Harahap, M. Yahya. 2013. Hukum Acara Perdata, Jakarta: Sinar Grafika.

Junanah, Yusdani dan Muhammad Husnl. 2014. 'Pudarnya Pesona Hukum Islam di PTAI', Millah, Vol.13, No. 2. Yogyakarta: Magister Ilmu Agama Islam UII, 324-339.

Kasiram. 2008. Metodologi Penelitian Kualitatif dan Kuantitatif, Malang: UIN Malang Press.

Moleong, Lexy J. 1999. Metodologi Penelitian Kualitatif, Bandung: PT. Remaja Rosdakarya.

Sugiono. 2014. Metode Penelitian Pendidikan, Pendekatan Kuantitatif, Kualitatif, Penelitian dan Pengembangan, Bandung: Alpabet.

Tim Penyusun Buku Panduan Akademik UIN SU. Buku Panduan Akademik UIN Sumatera Utara TA. 2015/2016, Medan: UIN Sumatera Utara.

UIN Sumatera Utara. 2017. Buku Pedoman Fakultas Syariah dan Hukum, Medan: UIN Sumatera Utara.

Waluyo, Bambang. 1991. Implementasi Kekuasaan Kehakiman Republik Indonesia, Jakarta: Sinar Grafika.

Yusdani. 2004. 'Posisi Tawar Sarjana Syari'ah Menurut UU Advokat', Al-Mawarid, Vol.13. Yogyakarta: Jurusan Syari'ah Fakultas Agama Islam UII. 324-339.

\section{Website}

Abdullah, "Rekrutmen Calon Hakim Tahun Anggaran 2017," https://www.mahkamahagung.go.id/id/artikel/2623/rekrutme n-calon-hakim-tahun-anggaran-2017, diakses tanggal 18 Agustus 2018.

"Banyak Anak Pejabat MA Yang Tidak Lolos Seleksi Calon Hakim" Kompas.Com, https://nasional.kompas.com/read/2017/10/25/14292671/bany 
Akseptabilitas Alumni Jurusan Al-Ahwal Al-Syakhsiyah .... $\mid 40$

ak-anak-pejabat-ma-yang-tak-lolos-seleksi-calon-hakim, diakses tanggal 23 Oktober 2018.

"Beberapa Anak Petinggi MA Tidak Lolos Seleksi Hakim 2017," Detik News, $\quad$ https://news.detik.com/beritald3664009/beberapa-anak-petinggi-ma-tidak-lolos-seleksihakim-2017, diakses tanggal 19 Oktober 2018.

“Cpns Mahkamah Agung 2017: 87\% Peserta Gagal di Tes Kompetensi Dasar".Kabar 24 http://kabar24.bisnis.com/read/20170925/15/692644/cpnsmahkamah-agung-2017-87-peserta-gagal-di-tes-kompetensidasar, diakses tanggal 4 Novemper 2017.

" CPNS Mahkamah Agung 2017: Lihat Nama Yang Lulus Seleksi Administrasi di Sini," ${ }^{\prime}$ Kabar 24, http://kabar24.bisnis.com/read/20170906/15/687469/cpnsmahkamah-agung-2017-lihat-nama-yang-lulus-seleksiadministrasi-di-sini, diakses tanggal 13 Oktober 2018.

Handar Subhandi, “Karakteristik Profesi Hakim dan Tanggung Jawab Profesi Hakim,"dalam http://handarsubhandi.blogspot.co.id/2014/06/katakteristiprofesi-hakim-dan.htnl, diakses tangal 7 Nopember 2017.

"Pastikan Lolos Tes SKD CPNS 2017, ini Passing Grade dan Rambu-Rambu Materinya", Solo Tribun, http://solo.tribunnews.com/2017/09/11/pastikan-lolos-tes-skdcpns-2017-ini-passing-grade-dan-rambu-rambu-materinya, diakses Jumat, 24 Agustus 2018

PA Purworejo, "Kode Etik dan Pedoman Prilaku hakim", http://pa-purworejo.go.id/web/pedoman-perilaku-hakim, diakses tanggal 7 Nopember 2017.

Mahkamah Agung," Lampiran 1 Surat Pansel Nomor 06/Pansel/MA/09/2017 tentang Daftar Kelulusan dan Peringkat SKD. https://www.mahkamahagung.go.id/id/pengumuman/2742/pe 
41 Ibnu Radwan Siddik Turnip \& Amal Hayati

ngumuman-hasil-seleksi-komoetensi-dasar-skd-cakim-ma-rita-2017. diakses pada tanggal 17 Oktober 2018.

Mahkamah Agung, "87 Akademisi Dari 21 Perguruan Tinggi

Negeri dan 1 Perguruan Tinggi Swasta Menguji Calon Hakim," https://www.mahkamahagung.go.id/id/artikel/2747 187-akademisi-dari-21-perguruan-tinggi-negeri-dan-1perguruan-tinggi-swasta-menguji-calon-hakim, diakses tgl 18 Agustus 2018.

Mahkamah Agung, "Surat Panitia Seleksi Calon Hakim di Lingkungan Mahkamah Agung RI Nomor 03/Pansel/MA/09/2017 tanggal 6 September 2017", https://www.mahkamahagung.go.id/id/pengumuman/2711/pe ngumuman-hasil-seleksi-administrasi-penerimaan-calonhakim-di-lingkungan-mahkamah-agung-ri-ta-2017, diakses tanggal 14 Oktober 2017

"Seleksi Calon Hakim Untuk Peradilan Agama Tak Tembus Kuota," Kompas.com. http://nasional.kompas.com/read/2017/10/06/18071821/seleksi -calon-hakim-untuk-peradilan-agama-tak-tembus-kuota, diakses tanggal 3 Nopember 2017.

\section{Dokumen}

Lampiran Surat Menteri Pendayagunaan Aparatur Negara dan Reformasi Birokrasi selaku Ketua Tim Pengarah Panselnas Nomor B/554/S.SM.01.00/2017 tanggal 3 November 2017 tentang Hasil Nilai Integrasi SKD dan SKB Seleksi CPNS Tahun 2017 Instansi Mahkamah Agung Unit Peradilan Agama Formasi Jabatan Calon Hakim

Lampiran Surat Menteri Pendayagunaan Aparatur Negara dan Reformasi Birokrasi selaku Ketua Tim Pengarah Panselnas Nomor B/554/S.SM.01.00/2017 tanggal 3 November 2017 tentang Hasil Nilai Integrasi SKD dan 
Akseptabilitas Alumni Jurusan Al-Ahwal Al-Syakhsiyah .... $\mid 42$

SKB Seleksi CPNS Tahun 2017 Instansi Mahkamah Agung Unit Peradilan Agama Formasi Jabatan Calon Hakim.

Peraturan Menteri PAN dan RB Nomor 20 Tahun 2017.

Surat Pansel Penerimaan Calon Hakim di Lingkungan Mahkamah Agung RI Tahun Anggaran 2017 Nomor 01/Pansel/MA/07/2017 tanggal 10 Juli 2017.

Slide Persiapan Seleksi Kompetensi Bidang Calon Hakim Mahkamah Agung Republik Indonesia, Calon Hakim Peradilan Agama Tahun 2017

\section{Wawancara}

Adhari, Agus. Alumni Jurusan AS, Wawancara Pribadi, Medan, 19 Oktober 2018.

Fahmi, Hidayatil. Alumni Jurusan AS, Wawancara Pribadi, 30 Agustus 2018.

Hayati, Amal. Ketua Jurusan Al-Ahwal Al-Syakhsiyah, wawancara pribadi, UIN Sumatera Utara Medan, 27 Agustus 2018

Idris, Muhammad. Alumni Jurusan AS, Wawancara Pribadi, Medan, 12 Oktober 2018.

Manullang, Muhammad Abdi. Alumni Jurusan, Wawancara Pribadi 30 Agustus 2018.

Nasution, Iqbal Rasyid. Alumni Jurusan AS, Wawancara Pribadi, Tanggal 29 Agustus 2018.

Zakarya, Fachruddin. Alumni Jurusan AS, Wawancara Pribadi, Medan, 3 Nopember 2017. 